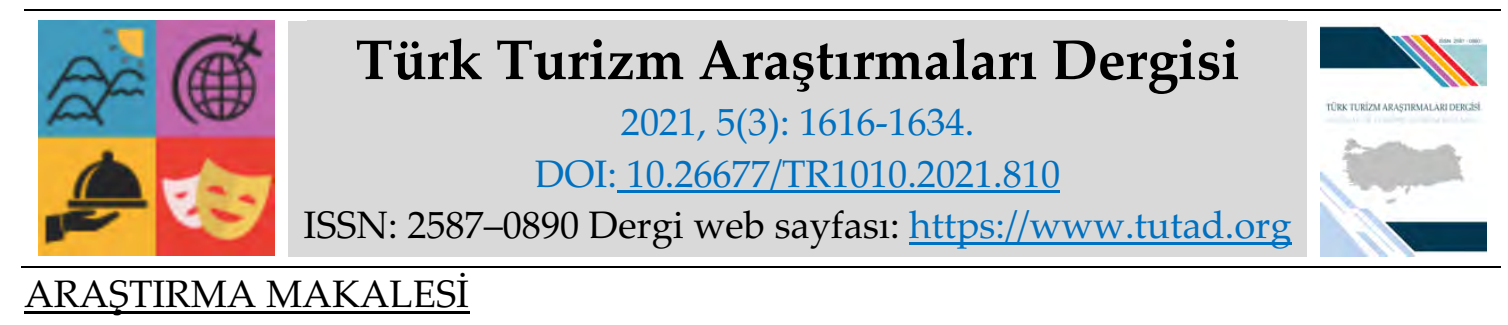

\title{
Turizm Rehberliği Öğrencilerinin Mesleki Kariyer Algılarının Belirlenmesi: Yükseköğrenim Düzeylerine Göre Bir Karşılaştırma
}

Dr. Öğr. Üyesi Sıla KARACAOĞLU, Bilecik Şeyh Edebali Üniversitesi, Uygulamalı Bilimler Fakültesi, Bilecik, e-posta: sila.karacaoglu@bilecik.edu.tr

ORCID: https://orcid.org/0000-0001-7724-22188

Doç. Dr. Duran CANKÜL, Eskişehir Osmangazi Üniversitesi, Turizm Fakültesi, Eskişehir, eposta: dcankul@ogu.edu.tr

ORCID: https://orcid.org/0000-0001-5067-6904

Öz

Araştırma, turizm rehberliği öğrencilerinin kariyer algılarını belirlemeyi amaçlamaktadır. Bu amaç doğrultusunda, araştırmada nicel yöntem benimsenmiştir Araştırmanın örneklemi olasılığa dayalı olmayan örnekleme türlerinden kolayda örnekleme yöntemine göre belirlenmiştir. Bu kapsamda Türkiye'deki devlet üniversitelerinde turizm rehberliği ön lisans, lisans ve yüksek lisans programlarında eğitimine devam eden 406 öğrenci araştırmanın örneklemini oluşturmaktadır. Araştırmada veri toplama tekniği olarak anket kullanılmıştır. Veriler Ocak 2020 - Mart 2020 tarihlerinde çevrimiçi platformdan elde edilmiştir. Elde edilen verilere faktör, korelasyon, varyans analizi (ANOVA), kümeleme ve çoklu uyum analizleri uygulanmıştır. Bulgular, turizm rehberliği öğrencilerinin kariyer algılarının "işin doğası", "işin zorluğu”, "işin değeri", "ekonomik getiri" “dini ifade özgürlüğ̈̈" ve "saygınlık” olmak üzere altı boyutta toplandığını; saygınlık boyutu dışında kalan diğer tüm faktörler için rehberlik mesleğinde kariyer yapma isteği duyduklarını göstermektedir. Öğrencilerin kariyer algıları genel olarak orta ve yüksek seviye aralığında olmakla beraber yükseköğrenim düzeylerine göre bir karşılaştırma yapıldığında ise lisans düzeyindeki öğrencilerin kariyer algılarının diğerlerine göre daha yüksek olduğu saptanmıştır. Bir diğer bulgu da erkek öğrencilerin kadınlara göre daha yüksek mesleki kariyer algısına sahip olduğudur. Son olarak öğrencilerin; gelecekte çalışma kartı almak istedikleri diller arasında ilk sırada İngilizcenin yer aldığı, bunu Rusça ve İspanyolcanın takip ettiği, bölgesel rehber olarak hizmet vermek istedikleri ve gelecekte uzmanlaşma bağlamında ise en çok arkeoloji, gastronomi ile sanat tarihi ve kültürel miras alanlarını tercih etmek istedikleri tespit edilmiştir.

Anahtar Kelimeler: Kariyer Alg1sı, Turizm Rehberliği, Yükseköğrenim, Turizm Rehberliği Öğrencileri.

Makale Gönderme Tarihi: 02.06.2021

Makale Kabul Tarihi: 04.09.2021

\section{Önerilen Atıf:}

Karacaoğlu, S. ve Cankül, D. (2021). Turizm Rehberliği Öğrencilerinin Mesleki Kariyer Algılarının Belirlenmesi: Yükseköğrenim Düzeylerine Göre Bir Karşılaştırma, Türk Turizm Araştırmaları Dergisi, 5(3): 1616-1634.

(C) 2021 Türk Turizm Araştırmaları Dergisi. 


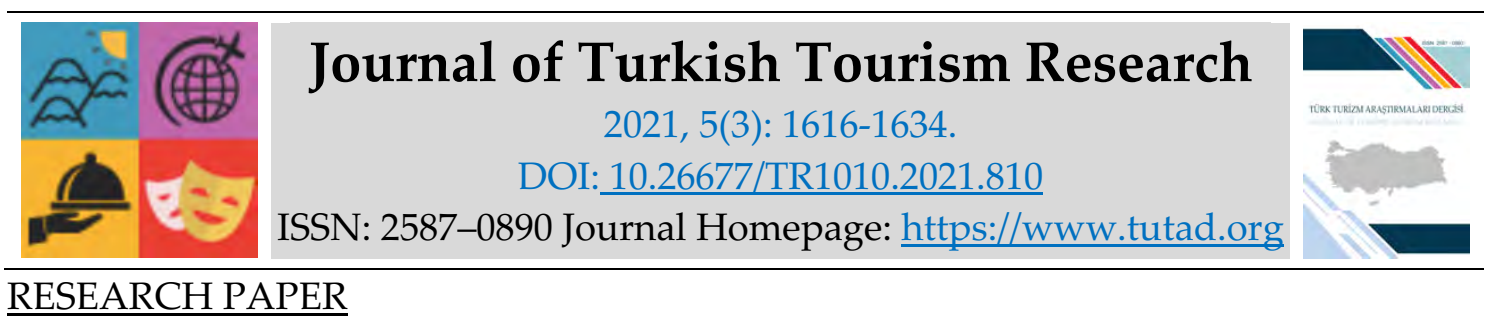

\title{
Determination of the Professional Career Perceptions of Tourism Guidance Students: A Comparison According to The Levels of Higher Education
}

Assistant Prof. Dr. Sıla KARACAOĞLU, Bilecik Şeyh Edebali University, Faculty of Applied Sciences, Bilecik, e-mail: sila.karacaoglu@bilecik.edu.tr

ORCID: https://orcid.org/0000-0001-7724-22188

Associate Prof. Dr. Duran CANKÜL, Eskişehir Osmangazi University, Faculty of Tourism, Eskişehir, e-mail: dcankul@ogu.edu.tr ORCID: https://orcid.org/0000-0001-5067-6904

\begin{abstract}
The study aims to determine the career perceptions of Tourism Guidance students. In line with this purpose, quantitative method was adopted in the study. The sample of the study was determined according to the convenience sampling method, which is one of the non-probabilistic sampling types. In this context, 406 students who continue their education in associate degree, bachelor's degree, and Master's degree in Tourism Guidance programs at Turkey's state universities constitute the sample of the study. Questionnaire was used as data collection technique in the research between January - March 2020. The data has been obtained from the online platform. Factor, correlation, analysis of variance (ANOVA), clustering and multiple fit analyses were applied to the data obtained. The findings show that tourism guidance students' career perceptions are grouped into six dimensions: "nature of work", "difficulty of work", "value of work", "economic return", "freedom of religious expression", and "prestige"; and that they urge to have a career on Tourism Guidance due to the factors apart from " prestige ". Although students' career perceptions are generally at medium and high-level range, when a comparison is made according to their higher education levels, it was found that the career perceptions of undergraduate students are higher than the others. Another finding is that male students have a higher perception of a professional career than females. Finally, it was determined that English, which is followed by Russian and Spanish, is the first preference among the languages that students want to receive a study card in the future, they want to serve as a regional guide, and in the context of specialization in the future, they will mostly prefer archeology, gastronomy and art history and cultural heritage.
\end{abstract}

Keywords: Career Perception, Tourism Guidance, Higher Education, Tourism Guidance Students.

Received: 02.06.2021

Accepted: 04.09.2021

Suggested Citation:

Karacaoğlu, S. and Cankül, D. (2021). Determination of the Professional Career Perceptions of Tourism Guidance Students: A Comparison According to The Levels of Higher Education, Journal of Turkish Tourism Research, 5(3): 1616-1634.

(C) 2021 Türk Turizm Araştırmaları Dergisi. 


\section{Gíriş}

Dünyada genel anlamıla turizm alanındaki profesyonel düzeydeki eğitim ve kursların büyük ölçüde 1980'lerde ve 1990'ların ilk yarısında ortaya çıktığı görülmektedir. Bu bakımdan turizm alanında sunulan profesyonel düzeydeki eğitim, diğer pek çok alanla kıyaslandığında nispeten daha yenidir (Cooper ve Westlake, 1989). Turizm eğitimi, bireye ilkeler edinme, yorumlama, değerlendirme ve analiz etme için gerekli becerileri veren bir sürece odaklanmaktadır. Daha açık bir ifadeyle, öğrencinin kritik yeteneklerini geliştirmektedir; mesleki ve entelektüel gelişime katkıda bulunmak için kavramsal konuların anlaşılmasını da teşvik etmektedir (Cooper ve Shepherd, 1997).

Günümüzde ise turizm endüstrisindeki farklı sektörlere ilişkin kariyer alanlarına yönelik artan taleple beraber dünya çapındaki birçok üniversitenin ve kolejin müfredatlarını rekabetçi bir şekilde genişlettiği, güçlendirdiği ve lisansüstü düzeyde de dereceler sunduğu bilinmektedir (Aloudat, 2017). Söz konusu eğilim, emek yoğun bir doğaya sahip olan bir diğer ifadeyle faaliyetlerin büyük çoğunluğunun çalışanlarla gerçekleştiği turizm endüstrisine (İşçeli ve Kılıç, 2018) iyi eğitimli ve kalifiye personel sağlama ihtiyacından kaynaklanmaktadır (Aloudat, 2017). Çünkü ülkeler turist memnuniyetinin ve turizmden daha fazla ekonomik pay alabilmenin ancak eğitimli çalışanlar aracılığıyla elde edilebileceğinin farkına varmış durumdadırlar (Arslanturk ve Altunoz, 2012). Bu bağlamda, turizm endüstrisinin farklı sektörlerinde gelecekte potansiyel iş gücü olacak öğrencilerin mesleğe ve kariyer hedeflerine yönelik görüşlerinin anlaşılması büyük önem arz etmektedir. Öğrencilerin sektöre yönelik tutumlarının belirlenmesi gerek insan kaynağının etkili kullanımı gerekse ilgili sektör verimliliği açısından da son derece gereklidir (Şahin ve Acun, 2016). Ayrıca, öğrencilerin mesleğe ilişkin algılarının ve tutumlarının saptanmasıyla; eğitimdeki eksikliklerin giderilmesi, eğitimin kalitesinin iyileştirilmesi ve gelecekte olası meslekten kopuşların önüne geçilmesi bağlamlarında da akademiye yol göstermesi beklenmektedir (Tolga, Kokmaz ve Atay, 2015).

İlgili literatür incelendiğinde turizm rehberliği öğrencilerinin mesleki tutumlarını ve potansiyel kariyerlerine yönelik algılarını ele alan sınırlı çalışmanın olduğu dikkat çekmektedir (Köroğlu, 2014; Şahin ve Acun, 2016; Aloudat, 2017; Çakıcı ve Eser, 2017; Çeşmeci, Çalışkan ve Özsoy; 2020). Buradan hareketle araştırmada, seyahatin başlangıcından bitişine değin turistlerle birebir etkileşimde olan ve ülke tanıtımında gönüllü bir kültür elçisi gibi çalışan turist rehberlerinin önemi göz önünde bulundurularak ilgili alanda ön lisans, lisans ve yüksek lisans düzeylerinde eğitim alan öğrencilerin mesleğe yönelik algılarının karşılaştırılmalı incelenmesi ve kariyer hedeflerinin belirlenmesi amaçlanmıştır. Literatür taraması sonucunda farklı yükseköğrenim düzeylerinde turizm rehberliği eğitimi gören öğrencilerin mesleğe yönelik algılarını karşılaştırmalı olarak inceleyen herhangi bir çalışmaya rastlanılmaması, araştırmanın özgünlügünü ortaya koyarken aynı zamanda araştırmanın bulgularının ilgili literatürün gelişimine katkı sağlaması hedeflenmektedir.

\section{LITERATÜR İNCELEMESİ}

\section{Türkiye'de Turist Rehberliği Eğitimi ve Mesleği}

Tarihi açıdan değerlendirildiğinde turist rehberliği insanoğlunun gerçekleştirdiği en eski faaliyetlerden biri olmakla birlikte (Rabotić, 2010), profesyonel ve çağdaş anlamda bir eğitim alanı olarak en eski, en titiz ve en saygın sistemlerden birine sahip olan Büyük Britanya'da 1951'den beri öğretilmektedir (Pond, 1993). Dünya genelinde ise geçmişte turist rehberleri genellikle eğitimsiz olsa da (McArthur, 1996) günümüzde rehberlik eğitimi artık çoğu gelişmiş ülkede yaygın hale gelmiş durumdadır. 
Türkiye'de profesyonel turist rehberliğinde eğitim ve sertifikasyon programları ekonomik gelişmelere paralel olarak 1980'li yıllardan itibaren hız kazanarak kurumsallaşmaya başlamıştır (Tolga vd., 2015). Ön lisans düzeyindeki ilk turist rehberliği mezunları, 1992 yılında Ankara Üniversitesi Başkent Meslek Yüksekokulu bünyesinde verilmiştir. Turizm Bakanlığınca, 1995 yılına kadar turist rehberliği eğitimi üç ve altı aylık kurslar şeklinde düzenlenmiş, 1995 yılında yönetmeliğe getirilen ek madde ile eğitimin fakülte ve yüksekokullarca yürütülmesi hedeflenmiştir. 1997 yılında ise o dönem Erciyes Üniversitesi'ne bağlı Nevşehir Turizm İsletmeciliği ve Otelcilik Yüksekokulu'nda lisans düzeyindeki ilk turist rehberliği eğitimi verilmeye başlanmıştır. Söz konusu gelişmelerle birlikte turist rehberliği eğitiminin üniversiteler tarafından verilmesinin önü açılmıştır (Yenipınar ve Zorkirişçi, 2013). 2012 yılında yürürlüğe giren 6326 sayılı "Turist Rehberliği Meslek Kanunu"na bağlı yönetmelikte turizm rehberliği yüksek lisans programlarından mezun olanların da mesleği icra etmeye hak kazandığı belirtilmiştir. İlgili yönetmelikte geçen bu ibarenin ardından üniversitelerde turizm rehberliği yüksek lisans programları açlmaya başlanmıştır (Deveci, 2016). 2019 yılı Yükseköğretim Kurumları Sınavı (YKS) yerleştirme sonuçlarına göre Türkiye'de devlet üniversitelerinde farklı isimlerle turizm rehberliği eğitimi veren ön lisans düzeyinde 23, lisans düzeyinde ise 41 program mevcuttur (Ölçme, Seçme ve Yerleştirme Merkezi Başkanlığı-ÖSYM, 2019). 2019-2020 eğitim öğretim yılında üniversitelerin sosyal bilimler enstitülerinin web sitelerinden alınan bilgilere göre aktif olarak Türkiye'deki devlet üniversitelerinde farklı isimlerle turizm rehberliği eğitimi veren yüksek lisans programlarının sayısı ise 14 üniversitede tezli, 9 üniversitede tezsiz olmak üzere toplam $24^{\prime}$ tür.

Turist rehberliği eğitimi, ülkemizde örgün ve yaygın eğitim olarak verilmektedir. Türkiye'de 6326 sayılı Turist Rehberliği Meslek Kanunu gereğince iki şekilde mesleği icra etmeye hak kazanılmaktadır. $\mathrm{Bu}$ bağlamda üniversitelerin turist/turizm rehberliği bölümlerinin yükseköğretim programlarından (ön lisans, lisans veya yüksek lisans) mezun olanlar ile Türkiye Turist Rehberliği Birliği (TUREB) tarafından açılan sertifika programını başarıyla bitirenler yabancı dil sınavını geçtikten ve yurt içi uygulama gezisini tamamladıktan sonra ruhsatname ve çalışma kartı alabilmektedirler. Yaygın eğitim kapsamında yer alan sertifika programları, TUREB ve Türkiye Seyahat Acentaları Birliği'nin (TÜRSAB) ortak önerileri ve Bakanlığın onayıyla turizm sektöründeki ihtiyaçlar dikkate alınarak, belirlenen dillerde Bakanlığın gözetimi ve denetiminde TUREB tarafından ülkesel ya da bölgesel olarak düzenlenmektedir. Bu doğrultuda, ülkesel sertifika programlarında en az yedi yüz, bölgesel sertifika programlarında ise bölge başına en az yüz elli ders saati verilmesi zorunludur (TUREB, 2020a).

Turist rehberliği eğitimi bir ülkenin coğrafyasına, tarihine, kültürüne, turizm değerlerine ve politikalarına göre değişkenlik göstermektedir (Tanrısever, Bektaş ve Koç, 2019). Günümüzde birçok üniversite derece, diploma ve sertifika seviyelerinde turist rehberliği eğitimi vermektedir. Turist rehberliğinin üniversitelerde akademik bir ana dal olması, mesleğin öneminin anlaşılmasından kaynaklanmaktadır (Aloudat, 2017). Bir turist rehberinin ve/veya tur yöneticisinin işi ilginç olmakla birlikte aynı zamanda da çeşitli güçlükler de içermektedir. Dolayısıyla, meslek seçimini turist rehberi olarak belirleyenlerin sektörün taşıdığı özellikler ve ihtiyaçlar nedeniyle birtakım özel beceri ve yeteneklere sahip olması gerekmektedir (Çakıcı ve Eser, 2017). Bu bağlamda, turist rehberlerinin eğitimleri iyi planlanmalı ve organize edilmelidir. Turist rehberi olabilmek ve gerekli standartlara ulaşmak için uygun eğitim almak şarttır (Pond, 1993). Eğitim, aynı zamanda turist rehberi lisansı almak için de bir ön koşuldur (Prakash, Chowdhary ve Sunayana, 2010). Bir mesleki düzenleme biçimi olarak genellikle "uygulama hakkı" olarak anılan lisanslama, oldukça kapsamlıdır ve küresel işgücü piyasasında değeri gün geçtikçe artmaktadır (Shani, 2017). Dünyanın en fazla turist çeken ülkeleri, rehberler için 
profesyonel turist rehberi lisanslama sistemlerine sahiptir ve rehber adaylarının eğitimleri, iş başında eğitimin yanı sıra üniversitede veya kolejde gerçekleşmektedir (McDonnell, 2001).

Genel olarak, akademik turizm literatürü, hükümetler ve turist rehberleri birlikleri, turist rehberlerinin profesyonel anlamda zorunlu olarak ruhsatlandırılmasını; turistlere sağlanan hizmetin kalitesi, destinasyon imajı ve kaçak rehberlerin çalışmasının önlenmesi vb. açılardan etkili ve meşru bir mekanizma olarak görmektedirler (Mak, Wong ve Chang, 2011; Shani, 2017). Sertifika ise birçok meslekte profesyonel veya teknik yeterliliğin sürdürülmesine ve geliştirilmesine yardımcı olmak için kullanılan bir mekanizmadır. Mesleğe, sorumluluk düzeyine ve yasal gerekliliklere bağlı olarak genellikle gönüllü işleyen bir süreçtir. Potansiyel olarak, turist rehberinin performansının iyileştirilmesine ve rehberlik standartlarının yükseltilmesine ve sürdürülmesine yardımcı olmak için de kullanılabilmektedir (Black ve Ham, 2005). Türkiye'de "rehberlikte uzmanlaşma eğitimi" ismiyle geçen sertifikasyon programları; turizmin 12 aya yayılarak çeşitlendirilmesini, bölgelere göre uzman turist rehberi yetiştirilmesini ve turist rehberlerinin çeşitli konularda eğitilmesini amaçlamaktadır (TUREB, 2020b). Söz konusu bağlamda turist rehberleri; Hititoloji, hristiyanlık tarihi, fauna, kuşların göçü vb. belirli bir konuda ve/veya sörf, avcılık, yürüyüş, sualtı araştırmaları vb. belirli bir etkinlik alanında uzmanlaşabilmektedirler (Köroğlu 2007; 2008). 6326 sayılı Turist Rehberleri Meslek Kanunu ve bu kapsamda hazırlanan Meslek Yönetmeliğinin "rehberlikte uzmanlaşma eğitimi" başlıklı 39. maddesinde, "Bakanlığın gözetim ve denetimi altında Birlik veya Birliğin uygun görüşü ile odalar tarafından uzmanlık eğitimi programları en az 5 gün olmak şartıyla, ücretli veya ücretsiz olarak teorik ve uygulamalı derslerin verilmesiyle düzenlenebilmektedir" ibaresi yer almaktadır (TUREB, 2020b).

\section{İLGİLI LITTERATÜR}

Öğrencilerin turizm endüstrisindeki çeşitli sektörlerde yer alan mesleklere yönelik alg1 ve tutumlarının, onların gelecekteki iş ve kariyer başarılarındaki kilit faktörü oluşturduğu aynı zamanda da turizmle ilgili işlerde çalışma isteklerini ve sektöre bağlllıklarını da ifade ettiği açıktır (Çakıcı ve Eser, 2017). Turizmin farklı alanlarında eğitim alan öğrencilere ilişkin yürütülen araştırmalar incelendiğinde öğrencilerin turizm endüstrisinin zorluklarını kabul etmelerine rağmen çalışmaya istekli olduğunu gösteren çalışmalar olduğu gibi (Kuşluvan ve Kuşluvan, 2000; Litvin, 2000; Köroğlu, 2014; Çuhadar ve Çetintürk, 2016) katılımcıların turizm alanında kariyer yapma konusunda kararsız olduğu (Roney ve Öztin, 2007) ve/veya uzun süreli kariyer hedeflemediğine işaret eden araştırma sonuçları da mevcuttur (Richardson, 2008, 2009; Richardson ve Butler, 2012; Aymankuy ve Aymankuy, 2013; Keleş, 2018). Öğrencilerin mesleğe ilişkin olumsuz tutum sergilediği araştırmaların bulguları turizm endüstrisinde kariyer yapmaya yönelik isteğin önündeki engelleri genel olarak; uzun ve düzensiz çalışma saatleri (Litvin, 2000; Duman, Tepeci ve Unur, 2006; Richardson, 2008; Aymankuy ve Aymankuy, 2013; Tuzunkan, 2018), işlerin doğası gereği stresli, yoğun, yorucu olması (Kuşluvan ve Kuşluvan, 2000; Duman vd., 2006; Richardson ve Butler, 2012; Tuzunkan, 2018), düşük ücret (Richardson, 2009; Richardson ve Butler, 2012; Aymankuy ve Aymankuy, 2013; Tuzunkan, 2018), ek gelirlerin yetersiz olması (Kuşluvan ve Kuşluvan, 2000; Duman vd., 2006), sosyal güvence (Aymankuy ve Aymankuy, 2013) ve iş garantisi olmayışı (Richardson, 2009; Duman vd., 2006; Roney ve Öztin, 2007), zorlu şartların kişisel yaşama ve aile yaşamına verdiği zararlar (Roney ve Öztin, 2007; Richardson, 2009; Richardson ve Butler, 2012) ve çalışanların toplum nezdinde saygı görmemesi (Duman vd., 2006; Aymankuy ve Aymankuy, 2013, Tuzunkan, 2018) vb. nedenlerle açıklamaktadır. 
Turist rehberlerinin turizm endüstrisinin çeşitli alanlarında yer aldığı ve turizmin çok önemli aktörleri (Cetin ve Yarcan, 2017) olduğu göz önüne alındığında, akademik turizm camiasında turist rehberliğine ilişkin araştırmaların daha az ilgi görmesi oldukça şaşırtıcıdır (McDonnell, 2001). İlgili literatür incelendiğinde turist rehberliği eğitimi alan ve geleceğin potansiyel rehber adaylarını oluşturan öğrencilere yönelik kısıtlı sayıda çalışmaya ulaşılması dikkat çekmiştir. Köroğlu (2014), turizm rehberliği alanında eğitim alan öğrencilerin meslek seçimi ile kişilik özellikleri arasındaki ilişkiyi tespit etmeyi amaçladığı araştırmada katılımcların çoğunluğunun kısmen bu mesleği isteyerek seçtiği, bununla beraber meslekten memnun oldukları ve mezun olduktan sonra turist rehberliği yapmayı istedikleri sonucuna ulaşmıştır. Tolga vd., (2015), seyahat acentacıllğg ve turizm rehberliği ile turizm rehberliği bölümlerinde eğitim alan öğrencilerin turizm endüstrisine yönelik tutumlarını ve kariyer yapma isteklerini karşılaştırmışlardır. Bu doğrultuda iki bölüm arasında turizm endüstrisine bakış açısı ve kariyer yapma isteğine yönelik boyutların anlamlılık düzeyleri incelendiğinde ücret, sosyal statü, işbirliği ve kariyer yapma isteği boyutlarında farklılıkların tespit edildiği sonucuna ulaşılmıştır. Elde edilen veriler, seyahat acentacılı̆̆1 ve turizm rehberliği eğitimi alan öğrencilerin turizm endüstrisini daha olumlu değerlendirdiklerini ve kariyer yapma isteklerinin turizm rehberliği bölümü öğrencilerine göre daha fazla olduğunu göstermektedir. Araştırmacılar söz konusu farklılığın nedenlerini seyahat işletmeciliği ve turizm rehberliği bölümünün daha kapsamlı bir müfredata sahip olmasına ve turist rehberliği dışında seyahat acentalarında da kariyer fırsatı sunmasına dayandırmışlardır. Araştırmanın bir başka sonucu da üst sınıf öğrencilerinin alt sınıf öğrencilerine göre mesleklerinde kariyer yapma isteklerinin daha az olduğudur. Yazarlar, söz konusu olumsuz bakış açısının sektörel çalışma deneyiminden kaynaklanabileceği yorumunda bulunmuşlardır. Şahin ve Acun (2016), turizm rehberliği alanında eğitim gören 298 öğrencinin mesleğe yönelik tutumlarını belirlemeye çalıştıkları araştırmalarının sonucunda öğrencilerin büyük çoğunluğunun mesleği isteyerek ve bilgi sahibi olarak tercih ettiklerini saptamışlardır. Benzer şekilde katılımcılar kariyer olarak kendilerine rehberlik mesleğini yakıştırdıklarını, gelecekte ise bilgili ve yeterli bir turist rehberi olarak mezun olacaklarını düşündüklerini de ifade etmişlerdir.

Yenipınar, Bak, Çınar, Birdir ve Çapar'ın (2016), turizm rehberliği birinci sınıf lisans öğrencilerinin mesleğe yönelik algılarını mecazlar aracılığıyla saptadıkları çalışmalarından elde edilen veriler katılımcıların meslek algılarının olumlu olduğunu ve mesleğin gerektirdiği bilgi, beceri ve sorumluluklar hakkında bilinç sahibi olduklarını göstermektedir. Bir diğer araştırma ise Çakıcı ve Eser (2017) tarafından Türkiye'de lisans düzeyinde turizm rehberliği eğitimi alan 1105 öğrencinin mesleğe dönük tutumlarının belirlenmesini amaçlamıştır. Yazarlar çalışmalarında turist rehberi adaylarını mesleğe dönük tutumlarına göre "kararsızlar", "rehberliği sevenler" ve "rehberlik sevdalıları" olarak 3 kümeye ayırmışlardır. Söz konusu öğrencilerden rehberlik sevdalıları kümesinde olanların mesleğe yönelik yaklaşımları en olumlu olarak tespit edilmiştir. Bu sonuçla birlikte üst sınıflara doğru ilerleyen öğrencilerde tutum değişikliği de gözlenmiştir. Sınıf düzeyinin artışına paralel olarak rehberlik sevdalılığı oranlarında düşme ve kararsızlık oranlarında artma eğilimleri olduğu saptanmıştır. Elde edilen bulgular, hem öğrencilerin okudukları alanla ilgili tam bilgi sahibi olmamalarına hem de eğitim gördükleri süreçte edindikleri olumsuz mesleki deneyime dayalı olarak bu tutumu sergilediklerine işaret etmektedir. Aloudat (2017), Ürdün'de lisans düzeyinde turist rehberliği eğitimi gören öğrencilerin mesleğe ilişkin kariyer algılarını araştırdığı çalışmasında genel olarak ilgili bölümün öğrencilerin ilk tercihini oluşturduğu ve katılımcıların algılarının olumlu olduğu sonucuna ulaşmıştır. Öğrenciler turist rehberliği mesleğinin özgürlük, yeni şeyler öğrenme ve yabancı insanlarla tanışma fırsatı sunan ilginç bir kariyer olduğunu ayrıca bu alanda yapılan kariyerin Ürdün'de geniş topluluklar arasında ve ailelerinde saygı duyulan bir meslek olarak kabul edildiğini de ifade etmişlerdir. Bununla beraber öğrencilerin turist rehberliği kariyeri 
hakkında bazı olumsuz algıları da bulunmaktadır. Öğrenciler söz konusu alanda yapılacak kariyeri; stresli ve yorucu bulduklarını, mesleğin istikrarsız bir gelir ile diğer daimi ofis iş kariyerlerine kıyasla daha düşük bir sosyal statüye sahip olduğunu ve aile hayatının olumsuz yönde etkilendiğini de düşündüklerini belirtmişlerdir. Ek olarak turist rehberi adaylarının mesleğe ilişkin rollerini ne ölçüde içselleştirdikleri de incelenmiştir. Elde edilen veriler katılımcıların çoğunluğunun turist rehberlerinin; ülkelerini destekleyen, arabulucu olan ve turist davranışını olumlu etkileyen rollerinin olduğu konusunda ortak fikre sahip olduğunu göstermektedir. Çeşmeci vd., (2020), lisans düzeyinde turizm rehberliği eğitimi alan öğrencilerin bireysel kariyer hedeflerini tespit etmeyi ve mesleğe ilişkin tutumlarını incelediği çalışmalarında katılımcların büyük kısmının turizm endüstrisinde kariyer yapmayı hedeflediği ve turist rehberliği mesleğini yapmaya istekli olduğu sonucuna ulaşmışlardır. Ek olarak, turizm rehberliği bölümünü bilinçli olarak seçen, stajyer rehber (apranti) olarak tura çıkan ya da seyahat acentalarında daha önce çalışma tecrübesi olan öğrencilerin turist rehberliği mesleğine ilişkin alg1 ve tutumlarının turizm endüstrisinin diğer alanlarında kariyer hedefi planlayanlara göre daha olumlu olduğu da belirlenmiştir. Söz konusu bulgu, turizm endüstrisinde deneyim kazanan öğrencilerin mesleğe yönelik olumsuz algı geliştirdikleri çalışmalardan farklılaştığını ortaya koyması açısından dikkat çekicidir (Roney ve Öztin, 2007; Richardson, 2009; Tolga vd., 2015; Çakıcı ve Eser, 2017).

Literatür taraması ile turizmin farklı bölümlerinde eğitim gören öğrencilerin meslekleriyle ilgili tutum ve algıları detaylı bir biçimde ortaya konulmaya çalışılmıştır. Buna göre gerek turizmin kendine özgü yapısından gerekse toplum nezdindeki bakış açısından kaynaklanan birtakım olumsuzlukların mevcut olduğu; söz konusu unsurların da öğrencilerin mesleki kariyer algılarını kimi zaman olumsuz etkilediği görülmektedir. Buradan hareketle bu araştırma, yakın gelecekte turizm endüstrisinin ana aktörlerinden biri olacak olan turizm rehberliği öğrencilerinin gelecekteki kariyer yollarıla ilgili kestirimlerde bulunmayı, mesleki kariyerlerine ilişkin algılarını daha iyi anlamayı ve tespit edilen olumsuz algıların iyileştirilmesiyle ilgili öneriler sunmayı amaçlamaktadır.

\section{ARAŞTIRMANIN YÖNTEMI}

$\mathrm{Bu}$ araştırma, turizm rehberliği öğrencilerinin kariyer algılarını belirlemeyi amaçlamaktadır. Bu amaç doğrultusunda, araştırmada nicel araştırma yöntemlerinden biri olan anket tekniği kullanılmıştır. Anket formu üç bölümden oluşmaktadır. Birinci bölümde turizm rehberliği öğrencilerinin kariyer algılarını belirlemeye yönelik 5'li Likert'e (1: kesinlikle katılmıyorum-5: kesinlikle katılıyorum) göre hazırlanmış ifadeler yer almıştır. Burada Aloudat (2017) tarafından geliştirilen turizm rehberliği kariyer algısı ölçeği kullanılmıştır. İkinci bölümde turizm rehberliği öğrencilerinin kariyer planlarını belirlemeye yönelik sorular ve üçüncü bölümde ise sosyodemografik sorular sorulmuştur.

Ölçeğin güvenilirliğini sınamak için Cronbach Alpha yöntemi kullanılmıştır. Cronbach Alpha yöntemine göre ölçeğin güvenilirliği $\alpha=, 90$ olarak hesaplanmıştır. Güvenilirlik analizi, herhangi bir konuda örneklemi oluşturan birimler üzerinden veri toplamak amacı ile geliştirilen ölçme aracını oluşturan ifadelerin kendi aralarında tutarlılık gösterip göstermediğini test etmek amacıyla kullanılmaktadır. Güvenilirlik katsayısı 0 ile 1 arasında değerler alır ve bu değer 1'e yaklaştıkça güvenilirlik artar (Tavşancıl, 2002; Ural ve Kılıç, 2006). Buna göre, bu araştırmada veri toplama aracı olarak kullanılan ölçeğin güvenilirlik düzeyinin yüksek olduğu söylenebilir (Kalaycı, 2010). Ayrıca rehberlik kariyer algısı ölçeğinin boyutları ile faktör analizi yapılmış ve boyutlar altı faktör altında toplanmıştır. 
Araştırma evrenini, Türkiye'deki devlet üniversitelerinde turizm rehberliği ön lisans, lisans ve yüksek lisans programlarında eğitimi devam eden öğrenciler oluşturmaktadır. 2019 YKS yerleştirme sonuçlarına göre kılavuzda Türkiye'de farklı isimlerle yer alan turizm rehberliği ön lisans programlarına yerleşen öğrenci sayısı 1115, lisans programlarına yerleşen öğrenci sayısı ise 1965'tir (ÖSYM, 2019). 2019-2020 eğitim öğretim yılında üniversitelerin sosyal bilimler enstitülerinin web sitelerinden alınan bilgilere göre yüksek lisans programlarında açılan kontenjan sayısı ise 280'i tezsiz 159'u tezli olmak üzere toplam 439'dur. 2019-2020 eğitim öğretim yılında yükseköğrenim düzeyinde turizm rehberliği eğitimi almaya başlayan öğrenci sayısı 3519'dur. Eğitim süresinin lisans düzeyinde dört yıl, ön lisans düzeyinde iki yıl olduğu düşünüldügünde yeni başlayan ve mevcut turizm rehberliği eğitimi alan öğrenci sayısının 10.000'nin üzerinde olduğu söylenebilir. Örneklem büyüklükleri tablosu incelendiğinde evren büyüklüğü 10.000 kişi ve üzerinde olduğunda 370 örneklem büyüklüğü yeterli olmaktadır. Araştırmanın evreni göz önüne alındığında örneklem sayısının evreni teslim etme düzeyinin yeterli olduğu görülmektedir. (Ural ve Kılıç, 2006). Araştırmanın gerçekleştirileceği örneklem grubunun belirlenmesi sırasında olasılığa dayalı olmayan örnekleme türlerinden kolayda örneklemeden faydalanılmıştır. Kolayda örnekleme yönteminin esası, ana kütleye ait ulaşılan her birimin örnekleme dâhil edilmesidir (Yazıcıŏ̆lu ve Erdoğan, 2004; Altunışık Coşkun, Bayraktaroğlu ve Yıldırım, 2010). Araştırmanın pilot çalışması 2019 yılı aralık ayı içerisinde Eskişehir Osmangazi Üniversitesi Tezsiz turist rehberliği bölümünde okuyan 75 öğrenci ile yüz yüze gerçekleştirilmiştir. Bu kapsamda elde edilen 75 anketin geçerlikleri test edilmiş ve uygun olmayan veya anlaşılamayan ifade olmadı̆̆ı sonucuna varılmıştır. Daha sonra belirlenen örneklem doğrultusunda veriler, Ocak 2020 - Mart 2020 tarihleri arasında Türkiye'deki devlet üniversitelerinin turizm rehberliği bölümünde okuyan öğrencilerle çevrimiçi ortamda anket çalışması gerçekleştirilerek toplanmıştır. Türkiye' nin farklı bölgeleri ve illerinde bulunan turizm rehberliği bölümlerindeki öğretim elemanları ile iletişime geçilerek öğrencilerine anketi yönlendirmeleri ve katılım sağlamaları istenmiştir. Öğretim elemanlarının yardımlarıyla çevrimiçi ortamda toplam 406 geçerli anket elde edilmiştir. Anketlerin uygulanabilmesi için etik kurul izni, Bilecik Şeyh Edebali Üniversitesi Bilimsel Araştırma ve Yayın Etiği Kurulu'nun 30.12.2020 tarihinde düzenlenen 13 sayılı toplantısında alınmışır. Anket formlarından elde edilen veriler, bilgisayar ortamında istatiksel analiz programina kodlanarak girilmiştir. Demografik değişkenlere ve kariyer planlarına ilişkin veriler, frekans, yüzde, değerleri kullanılarak değerlendirilmiş ve sonuçlar çizelge haline getirilip yorumlanmıştır. Verilerin analizinde, faktör, korelasyon, varyans analizi (ANOVA), kümeleme ve çoklu uyum analizlerinden yararlanılmıştır.

\section{BULGULAR}

Araştırmanın bu bölümünde turizm rehberliği öğrencilerinin sosyo-demografik özellikleri ile kariyer algılarına ilişkin bilgilere ve yapılan analizlerden elde edilen bulgulara yer verilmiştir. Turizm rehberliği öğrencilerine ilişkin sosyo-demografik bilgilerin yer aldığı Tablo 1'e bakıldığında, katılımcıların \%53'ünün kadın \%47'sinin erkek olduğu görülmektedir. Öğrencilerin \%89,7 oranı ile çoğunluğu bekar ve \%51,2 ile yarısından fazlası 2020 TL ve altı gelire sahiptir. Yaş dağılımları incelendiğinde; \%78,1'in 18-25 yaş aralığında, \%14,3'ün 26-35 yaş aralığında, \%5,4'ün 36-45 yaş aralığında, \%1,2'nin 46-55 yaş aralığında ve son olarak \%1'in ise 56 yaş ve üzerinde olduğu tespit edilmiştir. Öğrencilerin \%66,7'si lisans, \%18,5'i yüksek lisans, $\% 14,8$ 'i ön lisans düzeyinde eğitim görmektedir. Rehber adaylarının \%76,9'unun herhangi bir yerde çalışmayan, öğrenciler oluşturmaktadır. Turizm rehberliği öğrencilerinin eğitim aldıkları okulun bulunduğu bölgeler incelendiğinde; \%29,3'ü İç Anadolu, \%16,5'i Marmara, \%15,5'i 
Akdeniz, \%14,3'ü Karadeniz, \%13,8'i Ege, \%9,1'i Güneydoğu ve \%1,5'i Doğu Anadolu bölgesinde yer almaktadir.

\section{Turizm Rehberliği Öğrencilerinin Sosyo-Demografik Özelliklerine İlişkin Bulgular}

Tablo 1. Turizm Rehberliği Öğrencilerinin Sosyo-Demografik Özellikleri (n: 406)

\begin{tabular}{|c|c|c|c|}
\hline & & $\mathrm{n}$ & $\%$ \\
\hline \multirow{2}{*}{ Cinsiyet } & Kadın & 215 & 53,0 \\
\hline & Erkek & 191 & 47,0 \\
\hline \multirow{2}{*}{ Medeni Durum } & Evli & 42 & 10,3 \\
\hline & Bekar & 364 & 89,7 \\
\hline \multirow{7}{*}{ Gelir Durumu } & 2020 TL ve Alt1 & 208 & 51,2 \\
\hline & 2021-3000 TL & 46 & 11,3 \\
\hline & 3001-4000 TL & 46 & 11,3 \\
\hline & $4001-5000 \mathrm{TL}$ & 47 & 11,6 \\
\hline & $5001-6000 \mathrm{TL}$ & 25 & 6,2 \\
\hline & $6001-7000 \mathrm{TL}$ & 15 & 3,7 \\
\hline & 7001 TL ve Üzeri & 19 & 4,7 \\
\hline \multirow{3}{*}{ Eğitim Durumu } & Ön lisans & 60 & 14,8 \\
\hline & Lisans & 271 & 66,7 \\
\hline & Yüksek lisans & 75 & 18,5 \\
\hline \multirow{5}{*}{ Yaş } & $18-25$ & 317 & 78,1 \\
\hline & $26-35$ & 58 & 14,3 \\
\hline & $36-45$ & 22 & 5,4 \\
\hline & $46-55$ & 5 & 1,2 \\
\hline & 56 yaş ve üzeri & 4 & 1,0 \\
\hline \multirow{7}{*}{ İş Durumu } & İşveren & 7 & 1,7 \\
\hline & Ücretli Çalışan & 56 & 13,8 \\
\hline & Serbest Meslek Sahibi & 25 & 6,2 \\
\hline & Öğrenci & 312 & 76,9 \\
\hline & Emekli & 1 & 0,2 \\
\hline & Ev Hanımı & 2 & 0,5 \\
\hline & İşsiz & 3 & 0,7 \\
\hline \multirow{7}{*}{$\begin{array}{c}\text { Eğitim Aldığ }{ }_{1} \text { Okulun Bulunduğu } \\
\text { Bölge }\end{array}$} & Akdeniz & 63 & 15,5 \\
\hline & Doğu Anadolu & 6 & 1,5 \\
\hline & Ege & 56 & 13,8 \\
\hline & Güneydoğu Anadolu & 37 & 9,1 \\
\hline & İç Anadolu & 119 & 29,3 \\
\hline & Karadeniz & 58 & 14,3 \\
\hline & Marmara & 67 & 16,5 \\
\hline
\end{tabular}

Turizm rehberliği öğrencilerinin kariyer planlarına ilişkin bulgular Tablo 2' de gösterilmektedir. Öğrencilerin gelecekte çalışma kartı almak istedikleri dil ve/veya diller incelendiğinde ilk beş dil sırasıyla; İngilizce (\%92,6), Rusça (\%41,9) İspanyolca (\%34,5), Almanca (\%32,8) ve Arapça $(\% 22,9)$ olarak belirlenmiştir. Öğrencilerin \%70,9'u bölgesel, \%29,1'i ise ülkesel olarak turist rehberliği yapmayı istemektedir. Bölgesel yanıtını veren rehber adaylarının çalı̧̧mak istedikleri bölgeler sırasıyla; Ege (\%72,5), Akdeniz (\%69,1), Marmara (\%63,6), Karadeniz (\%57,6), İç Anadolu (\%50,4), Güneydoğu Anadolu $(\% 47,6)$ ve Doğu Anadolu $(\% 35,8)$ olarak tespit edilmiştir. Öğrencilerin gelecekte uzmanlık almak istediği alan ve/veya alanlar incelendiğinde ilk beş alanın; arkeoloji $(\% 60,6)$, gastronomi $(\% 53,4)$, sanat tarihi ve kültürel miras $(\% 43,8)$, fotoğraf $(\% 35)$ ile mimari (\%32) olduğu bulgusuna erişilmiştir. 


\section{Turizm Rehberliği Öğrencilerinin Kariyer Planlarına İlişkin Bulgular}

Tablo 2. Turizm Rehberliği Öğrencilerinin Kariyer Planlarına İlişkin Bulgular

\begin{tabular}{|c|c|c|c|}
\hline & & $\mathrm{n}$ & $\%$ \\
\hline \multirow{9}{*}{$\begin{array}{l}\text { Gelecekte Çalışma Kartı Almak } \\
\text { İstediği Dil ve/veya Diller* }\end{array}$} & İngilizce & 376 & 92,6 \\
\hline & Rusça & 170 & 41,9 \\
\hline & İspanyolca & 140 & 34,5 \\
\hline & Almanca & 133 & 32,8 \\
\hline & Arapça & 93 & 22,9 \\
\hline & Çince & 65 & 16 \\
\hline & İtalyanca & 62 & 15,3 \\
\hline & Fransizca & 56 & 13,8 \\
\hline & Japonca & 55 & 13,5 \\
\hline \multirow{2}{*}{ Gelecekte Planlanan Çalışma Türü } & Ülkesel & 118 & 29,1 \\
\hline & Bölgesel & 288 & 70,9 \\
\hline \multirow{7}{*}{$\begin{array}{l}\text { Bölgesel Yanıtı Veren Katılımcıların } \\
\text { Çalışmak İstedikleri Bölge * }\end{array}$} & Ege & 253 & 72,5 \\
\hline & Akdeniz & 241 & 69,1 \\
\hline & Marmara & 222 & 63,6 \\
\hline & Karadeniz & 201 & 57,6 \\
\hline & İç Anadolu & 176 & 50,4 \\
\hline & Güneydoğu Anadolu & 166 & 47,6 \\
\hline & Doğu Anadolu & 125 & 35,8 \\
\hline \multirow{9}{*}{$\begin{array}{l}\text { Gelecekte Uzmanlık Almak İstediği } \\
\text { Alan ve/veya Alanlar* }\end{array}$} & Arkeoloji & 246 & 60,6 \\
\hline & Gastronomi & 217 & 53,4 \\
\hline & Sanat tarihi ve kültürel miras & 178 & 43,8 \\
\hline & Fotoğraf & 142 & 35 \\
\hline & Mimari & 130 & 32 \\
\hline & Mavi yolculuk & 116 & 28,6 \\
\hline & Din & 11 & 27,3 \\
\hline & Şehir içi yürüyüş̧ & 105 & 25,9 \\
\hline & Ekoloji & 80 & 19,7 \\
\hline
\end{tabular}

Dip Not: " * " ile belirtilmiş sorulara katılımcılar birden fazla seçenek işaretlemiştir.

\section{Faktör ve Güvenilirlik Analizlerine İlişkin Bulgular}

Tablo 3. Faktör ve Güvenilirlik Analizlerine İlişkin Bulgular

\begin{tabular}{llllll}
\hline & Faktör & Mean & Öz değer & Açı. V. & C.Alpha \\
\hline & İşin Doğası & 4,10 & 9,22 & 27,27 &, 93 \\
\cline { 2 - 6 } & İşin Zorluğu & 3,46 & 4,40 & 10,04 &, 81 \\
\cline { 2 - 6 } $\begin{array}{l}\text { Rehberlik Kariyer Alg1S1 } \\
\text { Ölçeği (KMO=,89) }\end{array}$ & İşin Değeri & 2,68 & 1,79 & 8,74 &, 74 \\
\cline { 2 - 6 } & Ekonomik getiri & 3,59 & 1,53 & 7,90 &, 80 \\
\cline { 2 - 6 } & Dini İfade Özgürlüğü & 3,33 & 1,41 & 5,93 &, 89 \\
\cline { 2 - 6 } & Sayginlı & 2,06 & 1,14 & 5,16 &, 65 \\
\hline
\end{tabular}

Tablo 3'te araştırmada kullanılan ölçeklerin maddeleri için güvenirlik katsayıları incelenmiştir. Buna göre, Cronbach Alpha değeri $(0,90)$ olarak saptanmış ve iç tutarlılık katsayısı 0,70'in üzerinde çıkmıştır. Korelasyon matrisinden anlamlı faktörler çıkartılabileceğini ortaya koyan Bartlett Küresellik Testi $(7526,215)$ ve verilerin faktör analizine uygunluğunu belirleyen KMO test 
sonuçlarına bakılmıştır. Bartlett Küresellik Testi'nin $(\mathrm{p}<, 000)$ anlamlı sonuç, verdiği ve KMO değerine göre $(0,889>0,70)$ faktör analizine uygun olduğu belirlenmiştir. Verilerin normal dağılımlarını kontrol etmek için kullanılan yöntemlerden biri olarak basıklık ve çarpıklık değerlerine bakılmıştır. Değerlere bakıldığında, basıklık (-1,142 ve 4,778), çarpıklık $(-1,898$ ve $2,136)$ şeklinde $-2,+2$ ile $-2,+7$ arasında yer aldığı tespit edilmiştir.

\section{Kümeleme Analizi}

Tablo 4. Turizm Rehberliği Öğrencilerinin Kariyer Alg1 Düzeyi

\begin{tabular}{lcccc}
\hline & & $\mathbf{n}$ & $\mathbf{\%}$ \\
\hline \multirow{3}{*}{ Kariyer Alg1 Düzeyi } & Düşük & 33 & 0,8 \\
\cline { 2 - 4 } & Orta & 202 & 49,7 \\
\cline { 2 - 4 } & Yüksek & 171 & 42,1 \\
\hline
\end{tabular}

Turizm rehberliği öğrencilerinin kariyer algılarını ölçmek ve sınıflandırmak üzere ölçek ifadelerinde verdikleri cevaplar değerlendirilerek kariyer algı düzeyleri düşük, orta ve yüksek şeklinde üç kümeye ayrılmıştır. Kümeleme analizi bulgularına göre Tablo 4'te belirtildiği üzere; $\% 0,8(n=33)$ düşük seviye, \%49,7 $(n=202)$ orta seviye ve \%42,1 $(n=171)$ yüksek kariyer alg1 düzeyine sahip oldukları ortaya çıkmıştır.

\section{Faktörler Arasındaki Korelasyonlara İlişkin Bulgular}

Araştırmada faktörler arasında anlamlı düzeyde bir ilişkinin tespiti için korelasyon testi uygulanmıştır. Tablo 5'te kariyer algısı ölçek boyutları arasında ilişkiyi gösteren değerlere yer verilmiştir.

Tablo 5. Faktörler Arasındaki Korelasyonlara İlişkin Bulgular

\begin{tabular}{|c|c|c|c|c|c|c|}
\hline & $\begin{array}{c}\text { İşin } \\
\text { Doğası }\end{array}$ & İşin Zorluğu & İşin Değeri & $\begin{array}{c}\text { Ekonomik } \\
\text { Getiri }\end{array}$ & $\begin{array}{l}\text { Dini İfade } \\
\text { Özgürlüğü }\end{array}$ & Saygınlık \\
\hline İşin Doğası & 1 & & & & & \\
\hline İşin Zorluğu &, $253^{* *}$ & & & & & \\
\hline İşin Değeri & ,047 & $495^{* *}$ & & & & \\
\hline Ekonomik getiri &, $411^{* *}$ & $466^{* *}$ &, $324^{* *}$ & & & \\
\hline $\begin{array}{l}\text { Dini İfade } \\
\text { Özgürlüğü }\end{array}$ & $452^{* *}$ & $231^{* *}$ &, $314^{* *}$ &, $365^{* *}$ & & \\
\hline Saygınlık & ,045 & $156^{* *}$ & $142^{* *}$ & ,003 & ,003 & 1 \\
\hline
\end{tabular}

Kariyer algısı ölçeği altında toplanan toplam dört faktör arasında ilişkiler korelasyon analizi ile tespit edilmiştir. Değerler incelendiğinde "işin zorluğu" ile "işin doğası" boyutları arasında pozitif yönde düşük (,253); "işin doğası" ile "ekonomik getiri" ve "ifade özgürlüğü" arasında pozitif yönde orta düzey $(411 /, 452)$ ilişki saptanmıştır. "İşin zorluğu" ile "işin değeri" ve "ekonomik getiri" arasında pozitif orta düzey $(, 495 /, 466)$; "ifade özgürlüğ̈̈" ve "saygınlı" arasında ise pozitif yönde düşük ilişki bulunmuştur. Ayrıca, "ekonomik getiri" ve "ifade özgürlüğ̈̈" arasında orta düzey $(, 365)$ pozitif yönde bir ilişki saptanmıştır. 


\section{Tek Yönlü Varyans Analizine (ANOVA) İlişkin Bulgular}

Turizm Rehberliği Öğrencilerinin kariyer algı düzeyleri ile ölçek faktörleri arasındaki farklılıkları tespit etmek için yapılan ANOVA analizinde, saygınlık faktörü $(p=0,37)$ gruplar arasında bir farklılık göstermemiştir. Ancak diğer faktörler ile kariyer algı düzeyleri arasında anlamlı farklılıklar tespit edilmiştir. Söz konusu bulgu doğrultusunda turizm rehberliği öğrencilerinin saygınlık dışında tüm diğer faktörler için rehberlik mesleğinde kariyer yapma isteği duydukları söylenebilir (Tablo 6).

Tablo 6. Kariyer Algı Düzeyleri ile Ölçek Faktörleri Arasındaki Farklılığa İlişkin Bulgular

\begin{tabular}{|c|c|c|c|c|}
\hline & & Tukey & $\mathrm{F}$ & $\mathrm{p}$ \\
\hline \multirow{3}{*}{ Ekonomik Getiri } & Düşük & 2,27 & & \\
\hline & Orta & 3,23 & 121,10 & 0,00 \\
\hline & Yüksek & 4,28 & & \\
\hline \multirow{3}{*}{ İşin doğası } & Düşük & 1,89 & & \\
\hline & Orta & 4,30 & 429,38 & 0,00 \\
\hline & Yüksek & 4,29 & & \\
\hline \multirow{3}{*}{ İşin Zorluğu } & Düşük & 2,50 & & \\
\hline & Orta & 3,12 & 111,60 & 0,00 \\
\hline & Yüksek & 4,03 & & \\
\hline \multirow{3}{*}{ İşin Değeri } & Düşük & 2,24 & & \\
\hline & Orta & 2,12 & 122,15 & 0,00 \\
\hline & Yüksek & 3,43 & & \\
\hline \multirow{3}{*}{ Dini İfade Özgürlüğü } & Düşük & 1,77 & & \\
\hline & Orta & 3,04 & 70,94 & 0,00 \\
\hline & Yüksek & 3,97 & & \\
\hline \multirow{3}{*}{ Saygınlık } & Düşük & 1,81 & & \\
\hline & Orta & 2,00 & 0,99 & 0,37 \\
\hline & Yüksek & 1,98 & & \\
\hline
\end{tabular}

\section{Çoklu Uyum Analizine İlişkin Bulgular}

Turizm rehberliği öğrencilerinin kariyer algı düzeylerinin çalışma türü, eğitim alınan bölge, cinsiyet, yaş, gelir, eğitim, medeni durum ve iş durumu özelliklerine göre ilişkileri ortaya koymak amacıyla çoklu uyum analizi yapılmıştır. Çoklu uyum analizi kategorik hale getirilmiş verilerin değişimlerini ve korelasyon ilişkilerinin derecesini tek bir grafikte gösteren çok değişkenli analiz yöntemidir (Özdamar, 2010). Bu doğrultuda yapılan analiz neticesinde turizm rehberliği öğrencilerinin kariyer algı düzeyleri arasındaki farklılıklar tespit edilmiştir.

Çoklu uyum analizinde turizm rehberliği öğrencilerinin kariyer alg1 düzeyleri ve sosyodemografik özellikler arasındaki ilişkinin iki boyutta açıklandığı ortaya çıkmıştır. Çoklu uyum analizinde sıra ve sütunda yer alan değişkenlerin korelasyon ilişkilerine bakılmaktadır. Korelasyon ilişkisinden kuvvet derecesini gösteren tekil değerler eylemsizlik (inertia) değeri olarak adlandırılmaktadır (Kılıç, 2016; Birben, Ünal ve Umut, 2019). İlk boyut varyansın $\% 41,6$ 'sını açıklarken, ilişkinin eylemsizlik değeri 0,42; ikinci boyut varyansın \%21,9'unu açıklamış ve eylemsizlik değeri 0,22 olarak saptanmıştır. Böylelikle, iki boyut, toplamda varyansın \%63,6'sını açılamış ve eylemsizlik değeri 0,64 şeklinde tespit edilmiştir. 


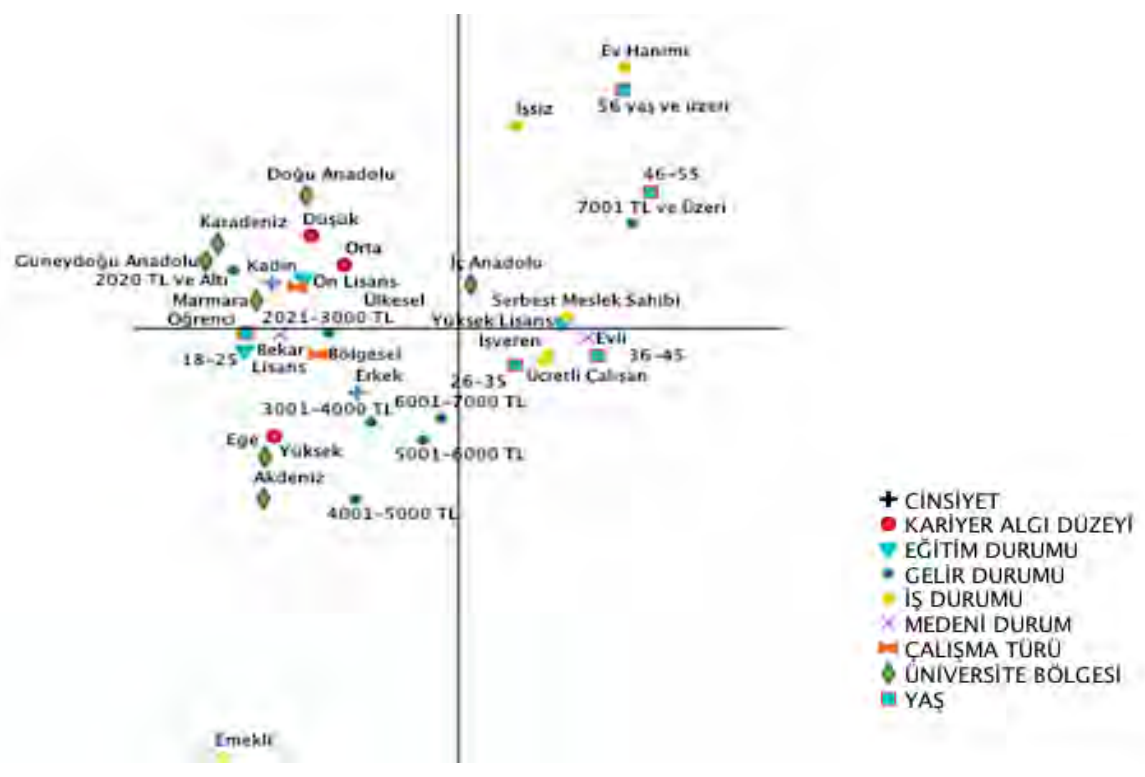

Şekil 1. Çoklu Uyum Analizine İlişkin Bulgular

Şekil 1'de turizm rehberliği öğrencilerinin okudukları programa, çalışma türüne ve eğitim alınan bölgeye göre incelendiğinde; ön lisans okuyan öğrencilerin orta düzeyde kariyer algısına sahip oldukları ve çalışma kartını ülkesel olarak almak istedikleri, Doğu Anadolu, Güneydoğu Anadolu, Karadeniz ve Marmara bölgelerinde eğitim aldıkları görülmektedir. Lisans düzeyindeki öğrenciler ise yüksek düzeyde kariyer algısına sahiptir, çalışma kartını bölgesel olarak almak istemektedir ve Ege ile Akdeniz bölgelerinde eğitim almaktadır.

Sosyo-demografik değişkenler açısından incelendiğinde, kadınların kariyer algılarının orta düzeyde, 2020 TL ve altı gelire sahip oldukları; erkeklerin ise kariyer algılarının yüksek, 30014000 TL arasında gelire sahip ve bekar oldukları görülmektedir. Diğer taraftan yüksek lisans eğitimi alan öğrencilerin İç Anadolu bölgesinde eğitim aldığı, iş sahibi, evli ve yaş ortalamasının yüksek olduğu saptanmıştır.

\section{SONUÇ ve ÖNERILER}

Turist rehberleri, turizm endüstrisinin bütün sektörlerinde paydaşlar için çalışabilen ve ziyaretçilere hizmet sağlayan bir meslek grubu olarak turizm sisteminde çok önemli bir yere sahiptir (Arslanturk ve Altunoz, 2012; Yen, Tsaur ve Tsai, 2018). Grönroos, (1978: 598), turist rehberinin endüstri içindeki önemini "bir sonraki turu satan rehberdir" diyerek vurgulamaktadır. Ayrıca bir ülkenin ve/veya destinasyonun temsili, turist deneyiminin kalitesi, turistin kalış süresi ve yerel bir topluluk için ekonomik faydaların oluşması bağlamında da turist rehberleri kritik rol oynamaktadır (Dahles, 2002). Turist rehberi, ziyaretçi ve ev sahibi ülke arasında bir köprü oluşturur, destinasyonun genel izleniminden ve turistleri memnuniyetinden fazlasıyla sorumludur (Melia, 2017). Rehberler, turistlere "gerçek anı" yaşatan ve geziyi güzel bir deneyime dönüştürebilen ya da tam tersi bozabilen öncü personellerdir. Bir destinasyon, iyi bir turist deneyimi için hazırlanmış olsa bile profesyonel olmayan bir turist rehberinin yaklaşım ve tutumu turistlerin deneyimini olumsuz hale getirebilmektedir (Prakash vd., 2010). Söz konusu bağlamda turist rehberinin yükseköğretim düzeyinde nitelikli ve kapsamlı bir eğitim almış olmasının gerekliliği daha iyi anlaşılmaktadır. 
Turizm rehberliği bölümünde okuyan öğrencilerin turizm endüstrinin gelecekteki potansiyel işgücü olduğu göz önünde bulundurulduğunda, onların düşüncelerinin anlaşılmasının oldukça önemli olduğu düşünülmektedir. Buradan hareketle bu araştırmada, Türkiye'deki devlet üniversitelerinde ön lisans, lisans ve yüksek lisans düzeyinde öğrenim gören turizm rehberliği öğrencilerinin mesleğe ilişkin kariyer algılarının araştırılması amaçlanmıştır. Araştırma sonuçları, genel olarak tüm düzeylerdeki turizm rehberliği öğrencilerinin kariyer algılarının $(n=406)$ orta ve yüksek seviye aralığında olduğunu göstermektedir. Elde edilen bu sonuç, öğrencilerin turist rehberliği mesleğine yönelik olarak olumlu algılara sahip olduklarına işaret etmektedir. Bunun yanı sıra, yükseköğrenim düzeylerine göre bir karşılaştırma yapıldığında lisans düzeyindeki öğrencilerin kariyer algılarının diğerlerine göre daha yüksek olduğu da saptanmıştır. Bu açıdan söz konusu bulgu, daha önce lisans düzeyinde turizm rehberliği öğrencileri üzerinde yürütülen çalışmaların bulgularıyla da benzerlik göstermektedir (Köroğlu, 2014; Şahin ve Acun, 2016; Çakıcı ve Eser, 2017; Aloudat, 2017; Çeşmeci vd., 2020). Mesleğe yönelik kariyer algısının lisans düzeyinde turizm rehberliği eğitimi alan öğrencilerin nezdinde daha yüksek olması iki şekilde yorumlanabilir. İlki, lisans düzeyindeki öğrencilerin mesleği bilgi sahibi olarak, severek ve isteyerek bilinçli bir tercihte bulundukları (Duman vd., 2006; Şahin ve Acun, 2016; Aloudat, 2017; Çakıcı ve Eser, 2017); ikincisi ise dört senelik lisans eğitimi süresince gerek derslerde gerekse gönüllü çalışma ve stajlarında mesleğin gerektirdiği bilgi, beceri ve sorumlulukları daha iyi anlamaları ve içselleştirmesiyle açıklanabilir (Şahin ve Acun, 2016; Yenipınar vd., 2016). Dolayısıyla, araştırmanın sonuçlarının genel itibariyle ilgili literatürle benzeştiği söylenebilir.

Araştırmadan elde edilen bir diğer bulgu, turizm rehberliğinde okuyan öğrencilerin işin doğası ile mesleğin getirdiği zorluklara rağmen bu alanda kariyer yapma isteklerinin olduğuna; bununla beraber turist rehberliğinin saygın görülmediğini düşündükleri için bu alanda kariyer yapma isteklerinin azaldığına işaret etmektedir. Söz konusu sonucun turizm rehberliği öğrencileri üzerinde araştırma yürüten Tolga vd.,'nin (2015) çalışmasıyla çeliştiği; Aloudat'ın (2017) çalışmasıyla ise kısmen benzeştiği gözlenmektedir. Tolga vd., (2015) turizm bölümlerinde öğrenim gören öğrencilere göre turizm rehberliğinde öğrenim görenlerin mesleklerinin toplumsal saygınlığı anlamında daha olumlu algıya sahip olduğu sonucuna ulaşmıştır. Aloudat'ın (2017) çalışması ise öğrencilerin, aileleri ve Ürdün'deki daha geniş topluluklar tarafından mesleklerinin çok saygı gördüğünü düşündüklerini; fakat kendilerinin turist rehberliği mesleğini diğer ofis tabanlı daimi iş kariyerlerine kıyasla daha düşük sosyal statüye ve saygınlığa sahip olarak algıladıklarını tespit etmiştir. Öte yandan, bu araştırmanın söz konusu bulgusunun; turizm rehberliği dışındaki farklı turizm bölümlerinde okuyan öğrencilerin mesleki algıları ile benzer olduğu görülmektedir. Literatürde yer alan önceki araştırmaların sonuçları farklı turizm bölümlerinde öğrenim gören öğrencilerin; aile ve çevresinin işleriyle gurur duyduğunu bilseler de kendilerinin mesleklerini önemli görmedikleri ve prestijsiz buldukları (Kuşluvan ve Kuşluvan, 2000; Aloudat, 2017), turizme ilişkin mesleklerin diğer mesleklere göre daha az saygıdeğer olduğunu algıladıkları (Litvin, 2000; Roney ve Öztin, 2007), turizme dayanan işlerin toplum nezdinde önemli, saygın ve itibarlı görünmediğini düşündükleri (Aymankuy ve Aymankuy, 2013) ve bu yüzden akrabalarına işlerinden bahsederken utandıklarını ifade ettikleri (Tuzunkan, 2018) çalışmaların bulguları ile örtüşmektedir.

$\mathrm{Bu}$ çalışmanın sonucunda ortaya çıkan turizm rehberliği öğrencilerinin mesleğe ilişkin saygınlık algılarının düşük olmasının altında yatan nedenlerin neler olabileceğinin gerek TÜRSAB, TUREB ve meslek odaları gerekse ilgili programlardaki akademik elemanların öğrencilerle kuracakları iletişim ile anlaşılmasının ve çözümlenmeye çalışılmasının oldukça önemli olduğu düşünülmektedir. $\mathrm{Bu}$ bağlamda turizm rehberliği öğrencileri, TÜRSAB ve TUREB profesyonelleri ile meslek odalarının dahil olduğu yüz yüze ve/veya çevrimiçi söyleşi, eğitim ve 
sektörel toplantılarla daha çok bir araya getirilmelidir. Söz konusu kurumların yetkililerinin mesleğe yönelik yapacağı bilgilendirmelerle ve motivasyonlarla öğrencilerin mesleğin önemini daha iyi anlaması sağlanabilir. Ayrıca, her ne kadar 2012 yılında Turist Rehberliği Meslek Kanunu ile mesleğin sosyal hakları güçlendirilerek güvence altına alınmış olsa da ilgili kurumlar tarafından çalışma koşullarının daha iyi hale getirilmesinin ve mesleğe daha fazla sahip çıkılmasının turizm rehberliği öğrencilerinin sosyal statü ve saygınlık algılarını artırarak mesleğe ilişkin daha olumlu tutumlar sergilemesine yardımcı olacağı değerlendirmesi de yapılabilir. Bu doğrultuda, turist rehberliği mesleğinde karşılaşılan başlıca en önemli iki sorun olarak görülen ve mesleğin saygınlığını azaltan kaçak rehberlik faaliyetlerini gerçekleştirenler ile rehberlere taban ücret altında ücret veren seyahat acentalarına yasal olarak daha kararlı ve sert yaptırımlar uygulanmasinın (Yarcan, 2007; Wang, Jao, Chan ve Chung, 2010; Mak vd., 2011; Karacaoğlu ve Sert, 2018) gerek toplumun gerekse turizm rehberliği öğrencilerinin mesleğe ilişkin olumlu algılar geliştirilmesine katkı sağlayabileceği söylenebilir. Ayrıca, T.C. Kültür ve Turizm Bakanlığı, TURSAB, TUREB ve birliğe bağlı meslek odaları tarafından mevcut turist rehberleri ile geleceğin turist rehberleri olmaya aday öğrencilerine mesleği özendirmek, turist rehberlerini motive etmek ve mesleği teşvik etmek amacıyla ödüller verilmesinin oldukça faydalı olacağı düşünülmektedir. Böylece, mesleğe ilişkin aidiyet duygusu kazandırılarak, mesleğin saygınlı̆̆ının ve hizmet kalitesini arttırılması da sağlanabilir. Araştırmada ortaya konan bir diğer bulgu da erkek öğrencilerin kadınlara göre daha yüksek mesleki kariyer algısına sahip olduğudur. Oluşan bu algının toplumda kültürel normlara bağlı olarak ortaya çıkan cinsiyet rol kalıpları, aile ve iş hayatını sürdürmede kadının üstlendiği görevler, turizm endüstrisinin farklı iş kollarının genelinde yaşanan cinsiyet ayrımcılığ düşünülmektedir (Köroğlu, Ulusoy Yıldırım ve Balıkoğlu, 2020). Bu doğrultuda kadın turist rehberlerini temsil edecek ve sorunlarını dile getirebilecek bir birliğin kurulması (Arslan ve Şimşek, 2018), aile-iş dengesini sağlayabilmeleri için kadın rehberlere eğitim ve psikolojik destek sağlanması ve sektöre yeni girecek kadın turist rehberlerinin mesleğe önyargılı başlamamaları ve önyargıları var ise bunların ortadan kalkması için meslekle tanışma seminerlerinin düzenlenmesi önerilebilir (Köroğlu vd., 2020).

Turizm rehberliği bölümlerinin bir eğitim kurumu olarak; öğrencileri en güncel bilgilerle donatması, staj ve mezuniyet sonrası kariyerleri için onlara yol göstermesi, uzmanlaşmanın önemini vurgulayarak öğrencileri buna teşvik etmesi, öğrenci ve sektör arasında güçlü ilişkiler kurması ve bireysel kariyerleri için öğrencileri motive etmesi beklenmektedir. Bununla beraber, gelecekteki potansiyel turist rehberi adaylarının Turist Rehberliği Meslek Yönetmeliği'ne göre okutulması gereken dersleri almalarının yanı sıra meslekte başarılı olabilmeleri için; öğrencilerde turizm bilincinin oluşması, turist rehberliği rollerinin içselleştirilmesi, iyi iletişim becerileri ile olumlu çalışma tutumunun edinilmesi, yaratıcılık, sistematiklik, organizasyon yeteneğinin geliştirilmesi ve akıcı dil becerileri gibi özellikleri kazanması gerekmektedir. Söz konusu bağlamda öğrencilere akademik bilginin yanı sıra kişisel gelişimlerini destekleyecek eğitimlerin ve seminerlerin TUREB ve kendisine bağlı meslek kuruluşları tarafından verilmesinin (Örn; farklı kültür, inanç ve milliyetten olan tur gruplarını yönetirken karşılaşacakları sorunları nasıl yönetecekleri ya da kişilere/gruplara nasıl davranmaları gerektiği vb.) öğrencilerin kişisel ve mesleki özelliklerini geliştirmesine fırsat vereceği ve meslekleriyle ilgili yetkinlik düzeylerini geliştirmelerine katkı sağlayacağı göz önünde bulundurulmalıdır (Gürsoy ve Karaman, 2019). Turist rehberlerinin gerek akademik gerekse kişisel eğitimlerini en iyi şekilde edinmeleri, kendilerini sürekli güncellemeleri ve becerilerini geliştirmeleri oldukça önemlidir (Lackey ve Pennisi, 2020). Çünkü yetersiz ve düşük nitelikli eğitim; turist rehberlerinin kendilerine daha az güven duymalarına, özsaygılarının azalmasına, performanslarının düşmesine, işlerini sevmeyerek yapmalarına neden olabileceği gibi aynı zamanda hizmet kalitesinin düşmesine ve turistlerin ülkeye ve mesleğe ilişkin olumsuz algılar geliştirmesine de sebep olabilir. 
Son olarak, turizm rehberliği öğrencilerinin gelecekte çalışma kartı almak istedikleri diller

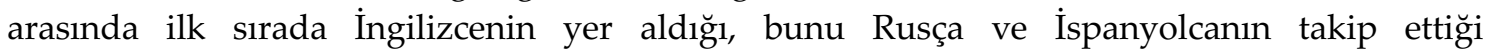
görülmektedir. Ayrıca katılımcıların çoğunluğun gelecekte ülkesel düzeyde değil, bölgesel düzeyde hizmet vermek istediği saptanmıştır. Bu kapsamda öğrencilerin ileride çalışmayı planladıkları ilk üç bölgenin sırasıyla; Ege, Akdeniz ve Marmara olduğu tespit edilmiştir. Türkiye'ye en fazla turist gelen bölgeler düşünüldügünde öğrencilerin söz konusu bölgelerde çalışmak ve uzmanlaşmak istemeleri beklendik bir sonuç olarak yorumlanabilir. Turist rehberi adaylarının gelecekte uzmanlık sertifikası almak istediği ilk üç alan içerisinde arkeoloji, gastronomi, sanat tarihi ve kültürel miras alanlarının ön plana çıkması da öğrencilerin gelecekte daha çok kültür odaklı turlarda uzmanlaşmak istediği biçiminde değerlendirilebilir. Söz konusu bulgu, özellikle son yıllarda uluslararası turizm hareketlerinde turistlerin kültür turizmi ve kültürel miras turizmine olan artan ilgilerine (Santa-Cruz ve López-Guzmán, 2017) paralel olarak oldukça doğal bir sonuç olarak görülebilir.

$\mathrm{Bu}$ araştırmanın, turist rehberliği öğrencilerinin kariyer algılarının daha geniş perspektiften değerlendirilebilmesi ve yükseköğrenim düzeyleri arasında karşılaştırma yapılabilmesi açısından ilgili literatüre katkı sağlaması beklenmektedir. Bununla beraber zaman ve maliyet kısıtlarından dolayı verilerin toplanmasında kolayda örnekleme yöntemi tercih edilmiş ve tam sayıma ulaşılamamıştır. Dolayısıyla bu araştırmanın sonucu Türkiye'de eğitim gören bütün turizm rehberliği öğrencileri için genelleştirilemez, bir diğer ifadeyle elde edilen bulgular sadece bu araştırmaya katılan öğrencilerin algılarını yansıtmaktadır. Ayrıca, kuramsal literatürdeki bulguların zenginleştirilmesi açısından daha fazla araştırmanın yapılması gerektiği düşünülmektedir. $\mathrm{Bu}$ doğrultuda, gelecekte araştırma yapacaklara örneklem sayısının artırılması, mümkünse tam sayıma gidilmesi tavsiye edilmektedir. Böylece, turizm rehberliğinde eğitim gören öğrencilerin mesleğe ilişkin kariyer algılarının daha farklı boyutlarda tartışılması ve karşılaştırmaların yapılması sağlanabilir.

\section{KAYNAKÇA}

Aloudat, A. S. (2017). Undergraduate Students' Perceptions of a Tour-Guiding Career, Scandinavian Journal of Hospitality and Tourism, 17(4): 333-344.

Altunışık, R., Coşkun, R., Bayraktaroğlu, S. ve Yıldırım, E., (2010), Sosyal Bilimlerde Araştırma Yöntemleri, SPSS Uygulamalı (6. Baskı). Adapazarı: Sakarya Yayıncılık.

Arslan, A. ve Şimşek, G. (2018) Kadın Turist Rehberlerinin Yaşadıkları Mesleki Sorunlar: Aydın Turist Rehberleri Örneği, Journal of Travel and Tourism Research, 13 :23-49.

Arslanturk, Y. and Altunoz, O. (2012). Practice-Trips: Efficiency and Quality Perceptions of Prospective Tour Guides, Procedia-Social and Behavioral Sciences, 62: 832-836.

Aymankuy, Y. ve Aymankuy, Ş. (2013). Turizm İşletmeciliği Eğitimi Alan Öğrencilerin Turizm Sektöründeki İstihdam ile İlgili Görüşleri ve Sektördeki Kariyer Beklentileri (Balıkesir Üniversitesi Turizm İşletmeciliği ve Otelcilik Yüksekokulu Örneği), Akademik Bakış Dergisi, 35: 121.

Birben, Ü., Ünal, H. E. ve Umut, İ. M. A. L. (2019). Orman Suçlarında Toplumsal Algı: Kırıkkale İli Örneği, Bartın Orman Fakültesi Dergisi, 21(2): 495-505.

Black, R. and Ham, S. (2005). Improving the Quality of Tour Guiding: Towards a Model for Tour Guide Certification, Journal of Ecotourism, 4(3): 178-195. 
Cetin, G., and Yarcan, S. (2017). The Professional Relationship Between Tour Guides and Tour Operators, Scandinavian Journal of Hospitality and Tourism, 17(4), 345-357.

Cooper, C. and Westlake J. (1989). Tourism Teaching into the 1990s, Tourism Management, 10(1): 69-73.

Cooper, C. and Shepherd, R. (1997). The Relationship Between Tourism Education and The Tourism Industry: Implications for Tourism Education, Tourism Recreation Research, 22(1): 34-47.

Çakıcı, C. ve Eser, S. (2017). Lisans Düzeyindeki Turizm Rehberliği Öğrencilerinin Mesleğe Dönük Tutumlarına Göre Kümelendirilmesi, Çă̆ Üniversitesi Sosyal Bilimler Dergisi, 14(2): 48-66.

Çeşmeci, N., Çalışkan, N. ve Özsoy, A. (2020). Turizm Rehberliği Öğrencilerinin Bireysel Kariyer Hedefleri ve Mesleğe Yönelik Tutumları, Journal of Tourism and Gastronomy Studies, 8(2): 852-869.

Çuhadar, M. ve Çetintürk, İ. (2016). Ön Lisans Düzeyinde Turizm Eğitimi Alan Öğrencilerin Kariyere Yönelik Algıları: Süleyman Demirel Üniversitesi Örneği, Mehmet Akif Ersoy Üniversitesi Sosyal Bilimler Enstitüsü Dergisi, 8(17): 51-69.

Dahles, H. (2002). The Politics of Tour Guiding: Image Management in Indonesia, Annals of Tourism Research, 29(3), 783-800.

Deveci, B. (2016). Uluslararası Skal Ödülü 'Turizm Eğitim Oscarı' Almış Turizm Rehberliği Ĕ̆itimi Veren Yükseköğretim Kurumlarının Hizmet Kalitesi Ölçümü: Turizm Rehberliği Öğrencileri Üzerine Bir Araştırma. Yayınlanmamış Yüksek Lisans Tezi, Balıkesir Üniversitesi, Balıkesir.

Duman, T., Tepeci, M. ve Unur, K. (2006). Mersin'de Yükseköğretim ve Orta Öğretim Düzeyinde Turizm Eğitimi Almakta olan Öğrencilerin Sektörün Çalışma Koşullarını Algılamaları ve Sektörde Çalışma İsteklerinin Karşılaştırmalı Analizi, Anatolia: Turizm Araştırmaları Dergisi, 17(1): 51-69.

Gronroos, C. (1978). A Service-Orientated Approach to Marketing of Services, European Journal of Marketing, 12(8): 588-601.

Gürsoy H. ve Karaman, S. (2019). Profesyonel Turist Rehberlerinin Kişisel Gelişimi ve Mesleki Donanımı Üzerine Bir Araştırma, Turist Rehberliği Dergisi, 2(2): 88-103.

İşçeli, Z. ve Kılıç, G. (2018). Lisans Düzeyinde Turizm Rehberliği Eğitimi Veren Fakültelerin Müfredatlarının İncelenmesi, Turist Rehberliği Dergisi (TURED), 1(1): 41-56.

Kalaycı, Ş. (2010). Spss Uygulamalı Çok Değiş̧kenli İstatistik Teknikleri. Ankara: Asil Yayın Dağıtım.

Karacaoğlu, S. ve Sert, A. N. (2018). Turist Rehberleri Meslek Sorunları Üzerine Bir Araştırma: Kapadokya Örneği, Journal of Tourism and Gastronomy Studies, 6(3): 81-90

Keleş, Y. (2018). Neden Turizm Eğitimi? Lisans Düzeyinde Turizm Öğrencilerine Yönelik Bir Araştırma, Journal of Tourism and Gastronomy Studies, 6(4): 219-236.

Kılıç, A.F. (2016). Uyum Analizi, YBS Ansiklopedisi, 3(1): 1-20.

Köroğlu, Ö. (2007). Değişen Tüketici Eğilimleri Çerçevesinde Özel İlgi Turizminin Geliştirilmesi ve Profesyonel Turist Rehberliği Mesleğinde Uzmanlaşmanın Önemi, Çeşme Ulusal Turizm Sempozyumu, 21-23 Kasım 2007. İzmir, Çeşme, ss: 226-234.

Köroğlu, Ö. (2008). Profesyonel Turist Rehberliği Mesleğinde Uzmanlaşma: Meslekte Uzmanlaşma Amacıyla Gerçekleştirilen Eğitim Programlarının İncelenmesi, III. Ulusal Eğirdir Turizm Sempozyumu, 17-19 Ekim 2008. Isparta: Eğirdir, ss: 260-272. 
Köroğlu, Ö. (2014). Meslek Seçimi ile Kişilik Özellikleri Arasındaki İlişkinin Belirlenmesi: Turizm Rehberliği Öğrencileri Üzerine Bir Araştırma, Süleyman Demirel Üniversitesi İktisadi ve İdari Bilimler Fakültesi Dergisi, 19(2): 137-157.

Köroğlu, Ö., Ulusoy Yıldırım, H., ve Balıkoğlu A. (2020). Kadın Turist Rehberlerinin Mesleki Sorunlarının Belirlenmesi, Mehmet Akif Ersoy Üniversitesi Sosyal Bilimler Enstitüsü Dergisi, (31), 2640.

Kuşluvan, S. and Kuşluvan, Z. (2000). Perceptions and Attitudes of Undergraduate Tourism Students Towards Working in the Tourism Industry in Turkey, Tourism Management, 21(3): 251269.

Lackey, N. Q., and Pennisi, L. (2020). Ecotour Guide Taining Program Methods and Characteristics: A Case Study from the African Bush, Journal of Ecotourism, 19(3), 217-232.

Litvin, S. W. (2000). Tourism Student Perceptions of a Travel Agency Career, Tourism and Hospitality Research, 1(4): 295-312.

Mak, A. H., Wong, K. K., and Chang, R. C. (2011). Critical Issues Affecting the Service Quality and Professionalism of The Tour Guides in Hong Kong and Macau, Tourism Management, 32(6): 1442-1452.

McArthur, S. (1996). Interpretation in Australia-Is It Running on Borrowed Time?, Australian Parks \& Recreation, 32(2): 33-36.

McDonnell, I. (2001). The Role of The Tour Guide in Transferring Cultural Understanding (Working Paper No. 3). Sydney, Australia: University of Technology, School of Leisure, Sport. Tourism, $1-14$.

Melia, D. (2017). A Career in Tour Guiding: A Case Study of Dublin, Ireland. Conference papers. 70. pp: 1-33. https://arrow.tudublin.ie/tfschmtcon/70.

Ölçme, Seçme ve Yerleştirme Merkezi Başkanlığı (ÖSYM) https://www.osym.gov.tr/TR,16889/2019-yks-yerlestirme-sonuclarina-iliskin-sayisalbilgiler.html (Erişim Tarihi: 12.12.2019).

Özdamar, K. (2010). Paket Programlarla İstatistiksel Veri Analizi-2. Eskişehir: Kaan Kitabevi.

Pond, K.L. (1993). The Professional Guide. New York: Van Nostrand Reinhold.

Prakash, M., Chowdhary, N. and Sunayana (2010). Tour Guides-Roles, Challenges and Desired Competencies: A Review of Literature, International Journal of Hospitality and Tourism Systems, 3(1): $1-12$.

Rabotić, B. (2010). Tourist Guides in Contemporary Tourism. International Conference on Tourism and Environment, 4-5 March, 2010, Sarajevo, Bosnia \& Herzegovina, pp. 353-364.

Richardson, S. (2008). Undergraduate Tourism and Hospitality Student's Attitudes Toward a Career in the Industry: A Preliminary Investigation, Journal of Teaching in Travel and Tourism, 8(1): 23-46.

Richardson, S. (2009). Undergraduates' Perceptions of Tourism and Hospitality as a Career Choice, International Journal of Hospitality Management, 28: 382-388.

Richardson, S. and Butler, G. (2012). Attitudes of Malaysian Tourism and Hospitality Students' Towards a Career in the Industry. Asia Pacific Journal of Tourism Research, 17(3):262-276.

Roney, A. S. and Öztin, P. (2007). Career Perceptions of Undergraduate Tourism Students: A Case Study in Turkey, Journal of Hospitality, Leisure, Sport and Tourism Education, 6(1): 4-17. 
Santa-Cruz, F. G., and López-Guzmán, T. (2017). Culture, Tourism and World Heritage Sites, Tourism Management Perspectives, 24, 111-116.

Shani, A. (2017). Reassessing Occupational Licensing of Tour Guides, Advances in Hospitality and Tourism Research (AHTR), 5(1):84-100.

Şahin, S. ve Acun, A. (2016). Turizm Rehberliği Öğrencilerinin Mesleğe Yönelik Tutumları, Gaziantep Üniversitesi Sosyal Bilimler Dergisi, 15(2): 563-580.

Tanrısever, C., Bektaş, İ. ve Koç, D. E. (2019). Dünyada Turist Rehberliği Eğitimi, Turist Rehberliği Dergisi (TURED), 2(1): 44-56.

Tavşancıl, E. (2002). Tutumların Ölçülmesi ve SPSS ile Veri Analizi. Ankara: Nobel Yayınları.

Tolga, Ö., Korkmaz, H. ve Atay, L. (2015). Lisans Düzeyindeki Turist Rehberliği Öğrencilerinin Mesleki Tutumlarına Yönelik Bir Araştırma, Seyahat ve Otel İşletmeciliği Dergisi, 12(2): 26-41.

Türkiye Turist Rehberliği Birliği (TUREB) (2020a). http://www.tureb.org.tr/tr/Page/Detail/75 (Erişim Tarihi: 13.04.2020).

Türkiye Turist Rehberliği Birliği (TUREB) (2020b). http://www.tureb.org.tr/tr/Page/Detail/78 (Erişim Tarihi: 13.04.2020).

Tuzunkan, D. (2018). Undergraduate Tourism Students' Perceptions and Attitudes Towards Tourism Industry: The Case of Daejeon, South Korea, GeoJournal of Tourism and Geosites, 21(1):103111.

Ural, A. ve Kılıç, İ. (2006). Bilimsel Araştırma Süreci ve SPSS ile Veri Analizi, Ankara: Detay Yayıncilik.

Wang, K. C., Jao, P. C., Chan, H. C., and Chung, C. H. (2010). Group Package Tour Leaders Intrinsic Risks, Annals of Tourism Research, 37(1), 154- 179.

Yarcan, Ş. (2007). Profesyonel Turist Rehberliğinde Mesleki Etik Üzerine Kavramsal Bir Değerlendirme, Anatolia: Turizm Araştırmaları Dergisi, 18(1), 33-44.

Yazıcıŏ̆lu, Y. ve Erdoğan, S. (2004). SPSS Uygulamalı Bilimsel Araştırma Yöntemleri (1. Baskı), Ankara: Detay Yayıncilı.

Yen, C. H., Tsaur, S. H., and Tsai, C. H. (2018). Tour Leaders' Job Crafting: Scale Development, Tourism Management, 69, 52-61.

Yenipınar, U. ve Zorkirişci, A. (2013). Türkiye ve Avrupa Birliği Ülkelerinde Turist Rehberliği Eğitimi, Çă̆ Üniversitesi Sosyal Bilimler Dergisi, 10(2): 111-136.

Yenipınar, U., Bak, E., Çınar, B., Birdir, S. S. ve Çapar, G. (2016). Turizm Rehberliği Bölümü Lisans Öğrencilerinin “Turist Rehberliği” Mesleğine İlişkin Algılarının Mecazlarla Analizi, 17. Ulusal Turizm Kongresi, Muğla Üniversitesi, 20-23 Ekim 2016, Bodrum, Muğla, ss: 1287-1296. 